ISSN: 2302-8556

E-Jurnal Akuntansi Universitas Udayana

Vol.24.3.September (2018):2148-2175

DOI: https://doi.org/10.24843/EJA.2018.v24.i03.p19

\title{
Pengaruh Volume Perdagangan Saham, Volatilitas Laba, Dividend Yield, Dan Ukuran Perusahaan Pada Volatilitas Harga Saham
}

\author{
Ni Wayan Sekar Andiani ${ }^{1}$ \\ Gayatri $^{2}$ \\ ${ }^{1}$ Fakultas Ekonomi dan Bisnis Universitas Udayana (Unud), Bali, Indonesia \\ email: andianisekar@gmail.com / Telp: 082340391640 \\ ${ }^{2}$ Fakultas Ekonomi dan Bisnis Universitas Udayana (Unud), Bali, Indonesia
}

\begin{abstract}
ABSTRAK
Penelitian ini bertujuan untuk mendapatkan bukti empiris mengenai pengaruh volume perdagangan saham, volatilitas laba, dividend yield, dan ukuran perusahaan pada volatilitas harga saham. Penelitian ini dilakukan pada perusahaan yang terdaftar dalam indeks LQ 45 di Bursa Efek Indonesia tahun 2012 sampai 2016. Penelitian ini mengambil populasi sebanyak 45 perusahaan dengan jumlah sampel 21 perusahaan dipilih melalui purposive sampling, sehingga jumlah sampel amatan selama 5 tahun menjadi 105 perusahaan. Teknik analisis data dalam penelitian ini adalah analisis regresi linier berganda. Berdasarkan hasil analisis ditemukan bahwa volume perdagangan saham tidak berpengaruh pada volatilitas harga saham. Volatilitas laba berpengaruh negatif pada volatilitas harga saham. Dividend yield berpengaruh positif pada volatilitas harga saham. Dan ukuran perusahaan berpengaruh negatif pada volatilitas harga saham.
\end{abstract}

Kata Kunci: volume perdagangan saham, volatilitas laba, dividend yield, ukuran perusahaan, volatilitas harga saham.

\begin{abstract}
This study aims to obtain empirical evidence on the effect of stock trading volume, earning volatility, dividend yield, and firm size on stock price volatility. This research was conducted on companies listed in index LQ 45 in Indonesia Stock Exchange 2012 until 2016. This research took the population of 45 companies with the number of samples of 21 companies selected through purposive sampling, so the number of samples observation for 5 years to 105 companies. The analysis technique in this research is multiple linear regression analysis. Based on the analysis results found that the stock trading volume does not affect the stock price volatility. Earning volatility has a negative effect on stock price volatility. Dividend yield has a positive effect on stock price volatility. And the firm size has a negative affects on stock price volatility.

Keywords: stock trading volume, earning volatility, dividend yield, firm size, stock price volatility.
\end{abstract}




\section{PENDAHULUAN}

Sebuah perusahaan di dalam menjalankan kegiatan operasionalnya membutuhkan dana, baik dari modal pemilik maupun dari pihak luar seperti investor. Pasar modal berfungsi sebagai sumber penghimpun dana atau sebagai sarana investasi baik berupa saham, obligasi, reksadana, istrumen derivatif maupun instrumen keuangan lainnya (Sutrisno, 2012). Saham (stock) merupakan salah satu instrumen keuangan yang paling dominan diperdagangkan. Investor sebelum memutuskan untuk berinvestasi melihat beberapa faktor seperti faktor return dan risiko. Informasi sebanyak mungkin mengenai harga saham dan kinerja perusahaan juga menjadi pertimbangan bagi investor dalam melaksanakan investasi.

Teori sinyal menekankan bahwa informasi perusahaan dapat direspon berbeda oleh investor, dimana tingkat keyakinan investor terhadap perusahaan mengakibatkan naik turunnya harga saham atau volatilitas harga saham. Volatilitas merupakan pengukuran statistik untuk fluktuasi harga suatu sekuritas atau komoditas selama periode tertentu (Tim Studi Volatilitas Pasar Modal Indonesia dan Perekonomian Dunia, 2011). Volatilitas ini terjadi karena adanya informasi baru yang masuk ke bursa. Volatilitas harga saham yang tinggi memungkinkan kenaikan dan penurunan harga saham juga semakin tinggi (Sova, 2013). Pada indeks LQ 45 harga saham bergerak fluktuatif dan dapat berubah setiap waktu (Rohmawati, 2017) seperti pada gambar di bawah ini: 


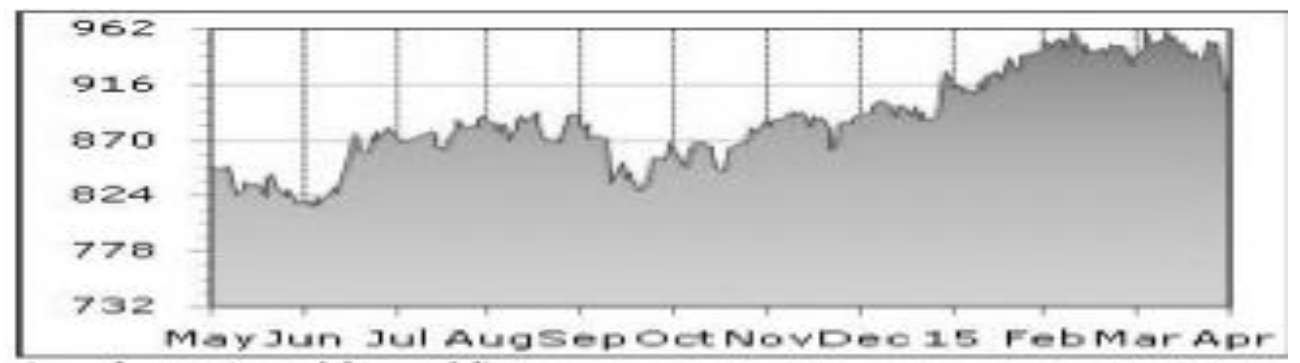

Gambar 1. Fluktuasi Harga Saham Indeks LQ 45 Mei 2014-April 2015

Pada gambar 1 menunjukkan perusahaan dalam indeks LQ 45 mengalami fluktuasi harga saham yang cukup signifikan pada bulan Mei 2014 - April 2015. Harga saham mengalami fluktuasi setiap bulannya dapat mengindikasikan kenaikan dan penurunan harga saham yang bervariasi. Memahami perilaku volatilitas dan hubungannya dengan pasar akan memberikan keuntungan dibanding sekadar menganalisis harga (Jain, 2011). Volatilitas bisa menjadi salah satu alat ukur risiko ketika berinvestasi di pasar modal (Zulfa, 2015).

Volume perdagangan saham yaitu jumlah lembar saham yang diperdagangkan di pasar modal yang dapat menunjukkan reaksi pasar dari respon investor terhadap informasi yang masuk ke bursa (Fauziah, 2013). Menurut penelitian Dewi \& Suaryana (2016) dan Rohmawati (2017) volume perdagangan saham berpengaruh positif pada volatilitas harga saham. Tetapi beberapa perusahaan yang ada di indeks LQ 45 tahun 2014 - 2015 menunjukkan bahwa meningkatnya volume perdagangan saham belum tentu dapat meningkatkan volatilitasnya, begitupula sebaliknya. Hal ini ditunjukkan di Tabel 1: 
Tabel 1.

Volume Perdagangan Saham dan Volatilitas Harga Saham Tahun 2014-2015

\begin{tabular}{|c|c|c|c|c|c|c|c|}
\hline \multirow[t]{2}{*}{ No } & \multirow{2}{*}{ Nama Perusahaan } & \multicolumn{3}{|c|}{$\begin{array}{c}\text { Volume Perdagangan } \\
\text { (dalam jutaan) }\end{array}$} & \multicolumn{3}{|c|}{ Volatilitas (\%) } \\
\hline & & 2014 & 2015 & Selisih & 2014 & 2015 & Selisih \\
\hline 1 & AALI (Astra Agro Lestari Tbk.) & 439 & 355 & -84 & 0,196 & 0,289 & 0,093 \\
\hline 2 & ASRI (Alam Sutera Realty Tbk.) & 22.540 & 22.460 & -80 & 0,211 & 0,369 & 0,158 \\
\hline 3 & BBCA (Bank Central Asia Tbk.) & 4.514 & 4.568 & 54 & 0,172 & 0,156 & $-0,016$ \\
\hline 4 & BMRI (Bank Mandiri Persero Tbk.) & 7.379 & 7.327 & -52 & 0,165 & 0,252 & 0,087 \\
\hline 5 & ICBP (Indofood CBP Sukses Makmur Tbk.) & 899 & 735 & -164 & 0,140 & 0,173 & 0,033 \\
\hline 6 & JSMR (Jasa Marga Persero Tbk.) & 1.929 & 1.720 & -209 & 0,212 & 0,213 & 0,001 \\
\hline
\end{tabular}

Tabel 1 menunjukkan tahun 2015, PT Astra Agro Lestari Tbk. terjadi penurunan volume perdagangan saham sebesar 84 juta, tetapi hal tersebut berbanding terbalik dengan volatilitas yang meningkat sebesar 9,3\%. PT. Bank Central Asia Tbk. mengalami peningkatan volume perdagangan saham sebesar 54 juta, namun berbanding terbalik dengan volatilitas yang mengalami penurunan sebesar 1,6\%. Dari Tabel 1 menunjukkan tinggi rendahnya volume perdagangan saham tidak dapat mencerminkan volatilitas harga suatu saham. Hal tersebut didukung oleh penelitian Safitri (2013) yang menemukan volume perdagangan saham tidak berpengaruh pada volatilitas harga saham.

Indikator kebijakan dividen yaitu tingkat imbal (hasil) dividen atau sering disebut dividen yield juga menjadi pertimbangan bagi investor dalam melaksanakan investasi. Dividend yield adalah besarnya tingkat pengembalian dari investasi yang ditanamkan investor dalam bentuk dividen (Khurniaji \& Raharja, 2013). Para manajer menggunakan kebijakan dividen untuk mempengaruhi risiko saham mereka dan terhadap komposisi risiko atau return portofolio investor (Anwar et al., 2015). Kebijakan dividen berpengaruh terhadap 
harga saham perusahaan karena dividen merupakan sumber yang memberikan sinyal kepada investor di pasar modal, dividen yang dibayarkan oleh perusahaan mencerminkan kemampuan perusahaan untuk mendapatkan laba dan prospek yang baik di masa yang akan datang (Yudiana \& Yadnyana, 2016). Penelitian Zakaria, et al. (2012), dan Khurniaji \& Raharja (2013) menemukan dividend yield berpengaruh pada volatilitas harga saham. Hal ini bertentangan dengan penelitian Fauziah (2013) yang menyatakan dividend yield tidak berpengaruh pada volatilitas harga saham.

Informasi yang ada di laporan keuangan tahunan juga menjadi pertimbangan investor untuk melakukan investasi seperti fluktuasi laba dan ukuran perusahaan tersebut. Nazir, et al. (2012) menyatakan bahwa volatilitas laba memiliki pengaruh positif signifikan pada volatilitas harga saham. Sedangkan penelitian yang dilakukan Anastassia \& Firnanti (2014) menyatakan volatilitas laba tidak berpengaruh pada volatilitas harga saham. Hashemijoo, et al. (2012) mengatakan ukuran perusahaan berpengaruh negatif pada volatilitas harga saham, sedangkan menurut Rinaldi (2014) menyatakan ukuran perusahaan berpengaruh positif namun tidak signifikan pada volatilitas harga saham.

Informasi maupun sinyal yang diperlukan investor dalam mengambil keputusan untuk berinvestasi bisa dilihat pada BEI melalui website www.idx.co.id. Perusahaan pada Indeks LQ 45 yang terdaftar di BEI bisa dijadikan sampel mewakili saham-saham di BEI (Tandelilin, 2010). Karena saham indeks LQ 45 terdiri dari gabungan saham-saham dengan kategori 
unggulan dan dengan pendapatan stabil yang mencakup 75\% kapitalisasi pasar, dipilih sebagai sampel dalam penelitian ini.

Kondisi dari saham yang ditransaksikan di pasar modal akan berdampak pada harga saham dilihat dari volume perdagangannya (Fauziah, 2013). Teori sinyal atau signalling theory menyatakan bahwa investor merespon berbeda informasi dari perusahaan yang mampu mempengaruhi fluktuasi harga saham. Dimana volume perdagangan saham dapat menunjukkan reaksi pasar terhadap respon dari investor tersebut. Terdapat tiga model yang menjelaskan volume perdagangan berhubungan dengan volatilitas. Pertama, mixture of distribution hypothesis, yaitu perubahan harga per transaksi yang terjadi berkaitan dengan volume transaksinya. Kedua, difference in opinion model, yang mengemukakan bahwa keyakinan berbeda yang dimiliki investor tentang nilai dari saham dapat menyebabkan transaksi perdagangan. Ketiga, asymmetric information model, yaitu investor melihat informasi privat dalam melakukan transaksi (Tim Studi Volatilitas Pasar Modal Indonesia dan Perekonomian Dunia, 2011). Dengan demikian informasi yang merupakan sinyal dari perusahaan dapat mempengaruhi volatilitas harga saham yang terlihat dari volume perdagangan atau seringnya saham tersebut diperjualbelikan pada bursa. Penelitian Sandrasari (2010), Dewi \& Suaryana (2016), dan Rohmawati (2017) mengungkapkan pengaruh positif volume perdagangan saham dengan volatilitas harga saham. Semakin banyaknya informasi mengenai saham yang diterima investor, mengakibatkan banyaknya penjualan saham, yang berdampak pada tingginya volume perdagangan saham. Tingginya volume perdagangan tersebut berakibat pada naiknya volatilitas. 
$\mathrm{H}_{1}$ : Volume perdagangan saham berpengaruh positif pada volatilitas harga saham.

Signalling Theory mengemukakan tentang bagaimana sebuah perusahaan seharusnya memberikan sinyal kepada pengguna laporan keuangan. Informasi yang diterima investor terlebih dahulu diterjemahkan sebangai good news atau bad news. Jika laba yang diperoleh perusahaan meningkat, informasi tersebut dapat dikatakan sinyal good news dan sebaliknya. Volatilitas laba adalah variasi besarnya laba yang dihasilkan perusahaan (Ghozali, 2012). Ketidakpastian laba merupakan risiko yang dihadapi perusahaan. Peningkatan yang terjadi pada volatiltas laba akan meningkatkan risiko kehilangan laba perusahaan bila terjadi terus-menerus akan mengganggu kegiatan operasional dari perusahaan. Semakin tinggi risiko bisnis suatu perusahaan maka dapat mempengaruhi harga saham. Investor dapat melihat perusahaan dengan laba yang berfluktuasi sebagai sinyal bahwa perusahaan tersebut sangat berisiko untuk diinvestasikan. Sinyal ini akan mendorong investor cepat menjual saham yang mereka miliki, maka dari itu saham dari perusahaan yang memiliki fluktuasi laba yang tinggi cenderung lebih volatil. (Khurniaji \& Raharja, 2013).

$\mathrm{H}_{2}$ : Volatilitas laba berpengaruh positif pada volatilitas harga saham.

Teori sinyal menyatakan bahwa reaksi harga saham disebabkan oleh kandungan informasi dari pengumuman pembagian dividen tunai kepada investor. Besarnya tingkat dividen yang dibagikan dikatakan sebagai sinyal yang menguntungkan oleh investor, sebaliknya penurunan dividen yang dibagikan dikatakan sebagai sinyal yang kurang menguntungkan. Penelitian Khurniaji \& Raharja (2013) dan Misbah, et al. (2013) menunjukkan bahwa dividend yield 
memiliki pengaruh negatif pada volatilitas harga saham. Semakin besarnya pembagian dividen, mengindikasikan perusahaan di masa mendatang akan profit. Dengan kata lain risiko yang dihadapi investor rendah sehingga dapat menurunkan tingkat volatilitas harga saham. Baskin (1989) menyatakan hubungan negatif dividend yield pada volatilitas harga saham dilihat dari duration effect, rate of return effect dan information effect. Berdasarkan duration effect, perusahaan yang memiliki dividend yield yang besar memiliki tanggapan yang lebih lambat pada fluktuasi harga saham. Berdasarkan rate of return effect, perusahaan dengan pembagian dividen yang kecil dinilai cenderung terlalu tinggi karena kategori perusahaan yang sedang tumbuh. Berdasarkan information effect, pembagian dividen yang besar merupakan informasi mengenai kestabilan dari perusahaan. Hal tersebut juga didukung oleh penelitian Nishat \& Irfan (2012) yang menyatakan bahwa dividend yield berpengaruh negatif pada volatilitas harga saham.

$\mathrm{H}_{3}$ : Dividend yield berpengaruh negatif pada volatilitas harga saham

Menurut Brigham \& Houston (2001) sinyal merupakan suatu tindakan yang diambil manajemen perusahaan, yang dapat memberikan petunjuk bagi investor tentang bagaimana manajemen memandang prospek perusahaan. Perusahaan dengan total aktiva besar menunjukkan arus kas perusahaan yang stabil, mampu menghasilkan laba dibanding perusahaan dengan total aset yang kecil dan sudah dianggap memiliki prospek yang baik dalam jangka waktu yang relatif lama. Penelitian Profilet \& Bacon (2013) di pasar saham US menunjukkan ukuran perusahaan berhubungan negatif dengan volatilitas harga saham. 
Demikian juga dalam penelitian Hashemijoo, et al. (2012) yang menemukan hubungan negatif ukuran perusahaan pada volatilitas harga suatu saham. Perusahaan besar memiliki diversifikasi aktivitas dan informasi publik yang lebih banyak sehingga mampu menurunkan volatilitas harga saham.

$\mathrm{H}_{4}$ : Ukuran perusahaan berpengaruh negatif pada volatilitas harga saham

\section{METODE PENELITIAN}

Jenis data yang digunakan dalam penelitian ini adalah data kuantitatif, yaitu data dalam bentuk angka yang dapat diukur dengan satuan hitung (Sugiyono, 2014). Sumber data yang digunakan dalam penelitian ini adalah data sekunder, yaitu data yang tidak langsung diberikan kepada peneliti, melainkan melalui orang lain atau mencari melalui dokumen sumber (Sugiyono, 2014). Sumber data sekunder penelitian ini melalui publikasi laporan keuangan tahunan yang telah diaudit di perusahaan yang terdaftar pada indeks LQ 45 tahun 2012-2016 dan pengambilan harga serta volume perdagangan saham melalui website www.idx.co.id. Dependent variable adalah variabel yang dipengaruhi dengan adanya variabel bebas (Sugiyono, 2014). Volatilitas harga saham digunakan sebagai variabel terikat dalam penelitian ini. Volatilitas harga saham adalah besar naik turunnya harga selama periode tertentu, menggunakan harga tertinggi dan harga terendah yang dirata-ratakan.

Varibel bebas atau independent variable adalah variabel yang mempengaruhi atau yang menjadi sebab perubahan atau timbulnya variabel terikat (Sugiyono, 2014). Variabel bebas dalam penelitian ini adalah volume perdagangan saham, yang didapat melalui website www.idx.co.id. Volatilitas laba 
Ni Wayan Sekar Andiani dan Gayatri. Pengaruh...

adalah ukuran naik turunnya laba yang diterima perusahaan setiap tahunnya (Khurniaji dan Raharja, 2013). Volatilitas laba merupakan standar deviasi dari perubahan laba. Fiechter (2011) dan Nazir et al. (2012) menggunakan earning before tax (EBT) sebagai ukuran yang relevan atas laba. Dividend Yield menggambarkan seberapa besar income return yang akan didapatkan oleh investor atas sejumlah uang yang mereka investasikan. Yaitu dengan membandingkan dividen per lembar saham dengan harga per lembar saham. Dan ukuran perusahaan diukur menggunakan logaritma natural (ln) dari total aset perusahaan (Jogiyanto, 2013).

Metode observasi nonpartisipan digunakan sebagai metode pengumpulan data dalam penelitian ini. Observasi dilaksanakan tanpa melibatkan diri ataus ebagai pengamat independen saja (Sugiyono, 2014:204). Berdasarkan observasi penelitian yang dilakukan, maka perusahaan dalam indeks LQ 45 yang dapat dijadikan sampel adalah sebanyak 21 perusahaan dengan proses penyeleksian sebagai berikut:

Tabel 2.

Hasil Seleksi Pemilihan Sampel

\begin{tabular}{|c|c|c|c|}
\hline & & Keterangan & $\begin{array}{l}\text { Jumlah } \\
\text { Perusahaan }\end{array}$ \\
\hline \multicolumn{2}{|l|}{ Populasi } & Perusahaan go public yang sahamnya masuk dalam indeks LQ 45 & 45 \\
\hline \multirow[t]{2}{*}{ Kriteria: } & 1 & $\begin{array}{l}\text { Perusahaan yang sahamnya tidak terdaftar dalam indeks LQ } 45 \\
\text { secara berturut-turut periode } 2012-2016\end{array}$ & $(21)$ \\
\hline & 2 & $\begin{array}{l}\text { Perusahaan dengan laporan keuangan yang tidak lengkap dan tidak } \\
\text { dengan satuan rupiah dalam indeks LQ } 45\end{array}$ & (3) \\
\hline \multicolumn{3}{|c|}{ Total perusahaan yang dijadikan sampel } & 21 \\
\hline \multicolumn{3}{|c|}{ Total sampel selama tahun 2012-2016 } & 105 \\
\hline
\end{tabular}


Teknik analisis data yang digunakan dalam penelitian ini adalah teknik analisis regresi linier berganda, yang berfungsi untuk menguji pengaruh variabel bebas pada variabel terikat, dan dapat menunjukkan arah hubungan variabelvariabel tersebut (Sugiyono, 2014). Adapun persamaan regresinya adalah sebagai berikut:

$$
Y=\alpha+\beta_{1} X_{1}+\beta_{2} X_{2}+\beta_{3} X_{3}+\beta_{4} X_{4}+\varepsilon
$$

Keterangan:

$\begin{array}{ll}Y & : \text { Volatilitas harga saham } \\ \alpha & : \text { Konstanta } \\ \beta_{1}-\beta_{4} & : \text { Koefisien regresi dari setiap variabel independen } \\ \mathrm{X}_{1} & : \text { Volume perdagangan saham } \\ \mathrm{X}_{2} & : \text { Volatilitas laba } \\ \mathrm{X}_{3} & : \text { Dividend yield } \\ \mathrm{X}_{4} & : \text { Ukuran perusahaan } \\ \varepsilon & : \text { Standar eror }\end{array}$

Statistik deskriptif mencerminkan gambaran dari data yang digunakan dalam penelitian ini yaitu: mean (nilai rata-rata), maximum (nilai tertinggi), minimum (nilai terendah), dan standar deviasi. Selanjutnya dilakukan pengujian penyimpangan asumsi klasik terhadap model regresi yang telah diolah yang meliputi uji normalitas, uji multikolinearitas, uji autokorelasi, dan uji heteroskedastisitas.

Koefisien determinasi digunakan untuk mengukur besarnya kemampuan model dalam menerangkan variasi variabel dependen (Ghozali, 2012:97). Nilai Adjusted $R^{2}$ yang kecil berarti kemampuan variabel-variabel indepeden dalam mejelaskan variasi variabel dependen amat terbatas (Ghozali, 2012:97). 
Uji Kelayakan Model (Uji F) untuk menguji variabel bebas memiliki pengaruh secara serempak pada variabel terikatnya (Ghozali, 2012:98). Yaitu dengan melihat nilai signifikansi kurang dari 0,05 maka dikatakan variabel independen secara serempak mampu memengaruhi variabel dependen.

Uji $t$ bertujuan untuk mengetahui kemampuan variabel bebas memengaruhi variabel terikatnya secara parsial (Ghozali, 2012:98). Yaitu dengan melihat signifikansi $\alpha>0,05$ maka dikatakan hipotesis ditolak, mempunyai arti variabel independen yang digunakan tidak berpengaruh pada variabel dependen. Jika nilai probabilitas signifikansi $<0,05$ maka hipotesis diterima, yang artinya variabel independen yang digunakan berpengaruh terhadap variabel dependen.

\section{HASIL DAN PEMBAHASAN}

Hasil pengujian statistik deskriptif dalam penelitian ini, dapat dilihat pada Tabel 3 berikut ini:

Tabel 3.

Hasil Statistik Deskriptif

\begin{tabular}{lcrrrr}
\hline \multicolumn{1}{c}{ Variabel } & N & Minimum & Maximum & Mean & $\begin{array}{c}\text { Std. } \\
\text { Deviation }\end{array}$ \\
\hline Volatilitas Harga Saham & 105 & 0,107 & 0,478 & 0,22507 & 0,068484 \\
Volume Perdagangan Saham & 105 & 0,270 & 31,672 & 6,80588 & 7,482403 \\
Volatilitas Laba & 105 & 0,018 & 0,307 & 0,10987 & 0,067832 \\
Dividend Yield & 105 & 0,000 & 6,400 & 1,89910 & 1,436224 \\
Ukuran Perusahaan & 105 & 29,653 & 34,577 & 31,65129 & 1,394344 \\
\hline
\end{tabular}

Sumber: Data diolah, 2017

Berdasarkan hasil pada Tabel 3 menunjukkan nilai rata-rata volatilitas harga saham sebesar 0,22507. Diartikan bahwa perusahaan cenderung memiliki volatilitas harga saham yang rendah. Standar deviasi lebih rendah dari nilai ratarata yaitu sebesar 0,068484. Artinya sebaran data satu dengan yang lainnya tidak 
tergolong tinggi atau sudah merata. Nilai minimum sebesar 0,107 dimiliki oleh PT Bank Negara Indonesia Tbk. pada tahun 2012. Dan nilai maksimum sebesar 0,478 dimiliki PT Tambang Batubara Bukit Asam Tbk. pada tahun 2015.

Berdasarkan hasil pada Tabel 3 menunjukkan nilai rata-rata volume perdagangan saham sebesar 6,80588. Diartikan bahwa perusahaan cenderung memiliki volume perdagangan saham yang rendah. Standar deviasi lebih tinggi dari nilai rata-rata yaitu sebesar 7,482403. Artinya sebaran data satu dengan data yang lainnya tergolong cukup tinggi. Nilai minimum sebesar 0,270 milyar lembar saham dimiliki oleh PT Gudang Garam Tbk. pada tahun 2014. Dan nilai maksimum sebesar 31,672 milyar lembar saham dimiliki PT Alam Sutera Realty Tbk. pada tahun 2013.

Berdasarkan hasil pada Tabel 3 menunjukkan nilai rata-rata volatilitas laba sebesar 0,10987. Diartikan bahwa perusahaan cenderung memiliki volatilitas laba yang rendah. Standar deviasi lebih rendah dari nilai rata-rata yaitu sebesar 0,067832. Artinya sebaran data satu dengan yang lainnya tidak tergolong tinggi atau sudah merata. Nilai minimum sebesar 0,018 dimiliki oleh PT Bank Mandiri Tbk. pada tahun 2016. Dan nilai maksimum sebesar 0,307 dimiliki PT Tambang Batubara Bukit Asam Tbk. pada tahun 2012.

Berdasarkan hasil pada Tabel 3 menunjukkan nilai rata-rata dividend yield sebesar 1,89910. Diartikan bahwa perusahaan cenderung memiliki dividend yield yang rendah. Standar deviasi lebih rendah dari nilai rata-rata yaitu sebesar 1,436224. Artinya sebaran data satu dengan yang lainnya tidak tergolong tinggi 
atau sudah merata. Nilai minimum sebesar $0,000 \%$ dan nilai maksimum sebesar 6,400\% dimiliki PT Tambang Batubara Bukit Asam Tbk. pada tahun 2015.

Berdasarkan hasil pada Tabel 3 menunjukkan nilai rata-rata ukuran perusahaan sebesar 31,65129. Diartikan bahwa perusahaan cenderung memiliki ukuran perusahaan yang besar. Standar deviasi lebih rendah dari nilai rata-rata yaitu sebesar 1,394344. Artinya sebaran data satu dengan yang lainnya tidak tergolong tinggi atau sudah merata. Nilai minimum sebesar 29,653 dimiliki oleh PT London Sumatera Plantation Tbk. pada tahun 2012. Dan nilai maksimum sebesar 34,577 dimiliki PT Bank Mandiri Tbk. pada tahun 2016.

Data penelitian yang digunakan dikatakan berdistribusi normal apabila nilai Asymp.Sig (2-tailed) lebih besar dari $\alpha=0,05$. Berdasarkan Tabel 4 di atas, nilai Asymp.Sig (2-tailed) dari model persamaan yang diuji sebesar 0,123 lebih besar dari 0,05 . Hal ini menunjukkan data yang digunakan dalam penelitian ini telah berdistribusi normal.

Uji multikolinearitas bertujuan untuk menguji apakah dalam model regresi ditemukan adanya kolerasi antar variabel bebasnya. Dalam penelitian ini nilai tolerance untuk semua variabel bebas diatas 0,1 dan nilai VIF kurang dari 10 , maka dapat dikatakan bahwa dalam penelitian ini tidak terdapat multikolinearitas antara variabel bebas.

Uji autokorelasi bertujuan untuk mengetahui adanya korelasi yang terjadi antara anggota-anggota dari serangkaian pengamatan, dimana model regresi yang baik adalah model yang bebas dari autokorelasi (Ghozali, 2013). Model regresi tidak terdapat autokorelasi apabila nilai Durbin-Watson lebih besar dari batas atas 
(dU) dan kurang dari 4-dU. Adapun hasil pengujian autokorelasi dari penelitian nilai DW yang dihasilkan sebesar 2,182. Oleh karena jumlah $\mathrm{n}=105$ dan $\mathrm{k}=4$, diperoleh nilai $\mathrm{dL}=1,6038$ dan $\mathrm{dU}=1,7617$ sehingga diperoleh juga nilai $4-\mathrm{dU}$ $=2,2383$, maka dapat dirumuskan kriteria $\mathrm{dU}<\mathrm{DW}<4-\mathrm{dU}$ yaitu $(1,7617<$ $2,182<2,2383)$. Hal ini menunjukkan data dalam penelitian ini bebas dari autokorelasi.

Uji heteroskedastisitas digunakan untuk mengetahui dalam model regresi terjadi ketidaksamaan variance atas residual dari pengamatan satu dengan yang lainnya. Model regresi yang baik adalah model regresi yang tidak terdapat gejala heteroskedastisitas (Utama, 2014). Metode Glejser digunakan dalam penelitian ini yaitu dengan meregresi nilai absolute residual dari model yang diestimasi terhadap variabel independen. Berdasarkan hasil penelitian, nilai signifikansi untuk semua variabel menunjukkan angka lebih dari 0,05. Maka, dalam penelitian tidak terjadi gejala heteroskedastisitas.

Hasil analisis regresi linier berganda dalam penelitian ini ditunjukkan pada Tabel 8 sebagai berikut:

Tabel 8.

Hasil Analisis Regresi Linier Berganda

\begin{tabular}{ccrrrrr}
\hline \multirow{2}{*}{ Model } & \multicolumn{2}{c}{$\begin{array}{c}\text { Unstandardized } \\
\text { Coefficients }\end{array}$} & \multicolumn{2}{c}{$\begin{array}{c}\text { Standardized } \\
\text { Coefficients }\end{array}$} & \multirow{2}{*}{ t } & \multirow{2}{*}{ Sig. } \\
\cline { 3 - 5 } & & \multicolumn{1}{c}{ B } & Std. Error & \multicolumn{1}{c}{ Beta } & & \\
\hline 1 & (Constant) & 0,982 & 0,173 & 0,170 & 5,671 & 0,000 \\
& $\mathrm{X}_{1}$ & 0,002 & 0,001 & 0,001 & 1,821 & 0,072 \\
& $\mathrm{X}_{2}$ & $-0,244$ & 0,112 & 0,112 & $-2,179$ & 0,032 \\
& $\mathrm{X}_{3}$ & 0,013 & 0,005 & 0,005 & 2,737 & 0,007 \\
& $\mathrm{X}_{4}$ & $-0,024$ & 0,005 & 0,005 & $-4,557$ & 0,000 \\
\hline
\end{tabular}

Sumber: Data diolah, 2017 
Berdasarkan hasil analisis regresi linier berganda pada Tabel 8 dapat dibuat persamaan sebagai berikut:

$$
Y=0,982+0,002 X_{1}-0,244 X_{2}+0,013 X_{3}-0,024 X_{4}+\varepsilon
$$

Koefisien determinasi bertujuan untuk mengetahui seberapa besar kemampuan variabel bebas dalam menerangkan variabel terikatnya (Ghozali, 2012:97). Koefisien determinasi dari penelitian ini yang disajikan dalam Tabel 9:

\section{Tabel 9}

Hasil Koefisien Determinasi

\begin{tabular}{crrrr}
\hline Model & R & R Square & \multicolumn{1}{c}{$\begin{array}{c}\text { Adjusted R } \\
\text { Square }\end{array}$} & $\begin{array}{c}\text { Std. Error of the } \\
\text { Estimate }\end{array}$ \\
\hline 1 & 0,453 & 0,205 & 0,173 & 0,062279 \\
\hline
\end{tabular}

Sumber: Data diolah, 2017

Pada Tabel 9, dapat dilihat nilai Adjusted $R$ Square sebesar 0,173. Yang artinya sebesar $17,3 \%$ variasi variabel independen mampu menjelaskan variasi variabel dependennya, sedangkan sisanya sebesar $82,7 \%$ dijelaskan oleh variabel lain.

Hasil Uji F dalam penelitian ini yang diolah menggunakan SPSS dapat dilihat pada Tabel 10 sebagai berikut:

Tabel 10.

Hasil Uji Kelayakan Model (Uji F)

\begin{tabular}{llrrrrr}
\hline Model & $\begin{array}{c}\text { Sum of } \\
\text { Squares }\end{array}$ & \multicolumn{1}{c}{ df } & $\begin{array}{c}\text { Mean } \\
\text { Square }\end{array}$ & F & Sig. \\
\hline 1 & Regression & 0,100 & 4 & 0,025 & 6,439 & 0,000 \\
& Residual & 0,388 & 100 & 0,004 & & \\
& Total & 0,488 & 104 & & & \\
\hline
\end{tabular}

Sumber: Data diolah, 2017

Nilai $F_{\text {hitung }}$ pada Tabel 10 sebesar 6,439 dengan signifikansi sebesar 0,000 lebih kecil dari nilai $\alpha=0,05$. Artinya semua variabel bebas dalam penelitian ini 
yaitu volume perdagangan saham, volatilitas laba, dividend yield, dan ukuran perusahaan secara serempak memengaruhi variabel terikatnya yaitu volatilitas harga saham.

Hasil Uji t dalam penelitian disajikan pada Tabel 11:

Tabel 11.

Hasil Uji Hipotesis (Uji t)

\begin{tabular}{lrr}
\hline \multicolumn{1}{c}{ Model } & $\boldsymbol{\beta}$ & \multicolumn{1}{c}{ Sig. } \\
\hline (Constan) & 0,982 & 0,000 \\
Volume Perdagangan Saham $\left(\mathrm{X}_{1}\right)$ & 0,002 & 0,072 \\
Volatilitas Laba $\left(\mathrm{X}_{2}\right)$ & $-0,244$ & 0,032 \\
Dividend Yield $\left(\mathrm{X}_{3}\right)$ & 0,013 & 0,007 \\
Ukuran Perusahaan $\left(\mathrm{X}_{4}\right)$ & $-0,024$ & 0,000 \\
\hline Sumber: Data diolah, 2017 & &
\end{tabular}

Berdasarkan hasil pada Tabel 11 menunjukkan nilai signifikansi Uji t untuk variabel volume perdagangan saham sebesar 0,072 lebih besar dari 0,05. Nilai $\beta_{1}=0,002$. Maka dikatakan volume perdagangan tidak berpengaruh pada volatilitas harga saham. Dengan demikian hipotesis pertama $\left(\mathrm{H}_{1}\right)$ ditolak. Teori sinyal yang menekankan bahwa informasi dari perusahaan dapat direspon berbeda oleh investor, yang ditunjukkan oleh volume perdagangan saham dan dapat mempengaruhi volatilitas harga saham, tidak mampu dibuktikan pada penelitian ini. Yang berarti naik atau turunnya harga saham perusahaan yang terdaftar dalam indeks LQ 45 di BEI tahun 2012-2016 tidak dipengaruhi oleh volume perdagangan saham. Hasil penelitian ini sesuai dengan temuan Safitri (2013), Agustinus, dkk. (2013), dan Ratnasari (2015) yang menyatakan volume perdagangan saham tidak berpengaruh pada volatilitas harga saham. Artinya bahwa investor berinvestasi di pasar modal tidak selalu memperhatikan volume perdagangan saham. Konsep supply dan demand menunjukkan harga saham akan 
naik akibat banyaknya investor yang menginginkan saham tersebut. Akan tetapi faktor penentu perubahan naik turunnnya harga saham tidak hanya faktor permintaan dan penawaran saham saja, melainkan tren dan situasi ekonomi makro yang terjadi pada periode-periode tertentu juga mendasari pergerakan harga saham tersebut. Selain itu perbedaan komoditi yang diperjualbelikan pada setiap sampel perusahaan juga dapat mengakibatkan perbedaan volume perdagangannya.

Berdasarkan hasil Tabel 11 menunjukkan nilai signifikansi Uji t untuk variabel volatilitas laba sebesar 0,032 lebih kecil dari 0,05 . Nilai $\beta_{1}=(-0,244)$. Maka dikatakan volatilitas laba berpengaruh negatif pada volatilitas harga saham. Dengan demikian hipotesis kedua $\left(\mathrm{H}_{2}\right)$ ditolak. Penelitian ini dapat membuktikan teori sinyal tentang bagaimana seharusnya sebuah perusahaan memberikan sinyal kepada pengguna laporan keuangan. Informasi yang diterima oleh investor akan ditanggapi sebangai sinyal good news atau bad news. Jika laba perusahaan meningkat, maka hal tersebut tergolong good news, begitupula sebaliknya. Dalam penelitian ini investor yang berinvestasi pada perusahaan yang terdaftar dalam indeks LQ 45 tahun 2012-2016 cenderung menganggap fluktuasi laba yang tinggi sebagai sinyal yang jelek (bad news) yaitu mencerminkan resiko. Karena lebih sulit memprediksi laba di masa mendatang ketika volatilitasnya tinggi. Hasil penelitian ini mendukung temuan Yesi (2015), Mobarak \& Mahfud (2017), dan Rowena \& Hendra (2017) yang menyatakan volatilitas laba berpengaruh negatif pada volatilitas harga saham. Yang artinya investor menggunakan ukuran tingkat volatilitas laba untuk memprediksi harga saham di pasar modal. Yakni semakin tinggi volatilitas laba yang dimiliki perusahaan cenderung mengurangi minat 
investor untuk menanamkan modalnya di pasar modal atau dapat menurunkan tingkat volatilitas harga saham. Naik turunnya laba dapat membuat perusahaan sulit mendapatkan dana eksternal, karena perusahaan tidak stabil. Semakin tinggi tingkat volatilitas laba, maka capital gain yang akan didapatkan oleh investor semakin besar pada saat laba mencapai tingkat maksimal. Sehingga investor cenderung tetap mempertahankan saham yang dimilikinya (hold) untuk jangka waktu ke depan. Oleh karena tidak banyak penjualan yang terjadi, maka tingkat volatilitas harga saham cenderung rendah. Karena kenaikan maupun penurunan harga saham ditentukan dari keputusan investor dalam membeli ataupun menjual sahamnya.

Berdasarkan hasil pada Tabel 11 menunjukkan signifikansi Uji t untuk variabel dividend yield sebesar 0,007 lebih kecil dari 0,05. Nilai $\beta_{1}=0,013$. Maka dikatakan dividend yield berpengaruh positif pada volatilitas harga saham. Sehingga hipotesis pertama $\left(\mathrm{H}_{1}\right)$ ditolak. Penelitian ini dapat membuktikan teori sinyal yang menjelaskan bahwa pengumuman pembagian dividen tunai mempunyai kandungan informasi yang mengakibatkan adanya reaksi harga saham. Semakin besarnya dividen yang dibagikan dianggap sebagai sinyal yang menguntungkan atau menimbulkan reaksi harga saham yang positif. Sebaliknya penurunan dividen yang dibagikan dianggap sebagai sinyal mengenai prospek perusahaan kurang menguntungkan, atau menimbulkan reaksi harga saham yang negatif. Dalam penelitian ini investor cenderung menanggapi pembagian dividen yang tinggi sebagai sinyal postif sehingga mampu mempengaruhi volatilitas harga saham. Hasil penelitian ini mendukung temuan Anastassia \& Firnanti (2014), Yesi 
(2015), dan Nuridawati (2015) yang menyatakan dividend yield berpengaruh positif pada volatilitas harga saham. Hasil penelitian ini mengindikasikan bahwa meningkatnya dividend yield dapat berpengaruh pada tinggi rendahnya minat investor untuk menanamkan modalnya di pasar modal dan berdampak bagi para pemegang saham. Peningkatan dividen yang dibayarkan dapat dianggap sebagai sinyal yang menguntungkan bagi investor dan para pemegang saham, sehingga menimbulkan reaksi harga saham yang positif. Dengan meningkatnya kemampuan perusahaan memperoleh laba, yang menyebabkan semakin besarnya dividen yang dibagikan hal ini akan menyebabkan peningkatan harga saham.

Berdasarkan hasil pada Tabel 11 menunjukkan signifikansi Uji t untuk variabel ukuran perusahaan sebesar 0,000 lebih kecil dari 0,05 . Nilai $\beta_{1}=(-$ 0,024). Maka dikatakan ukuran perusahaan berpengaruh negatif pada volatilitas harga saham. Sehingga hipotesis pertama $\left(\mathrm{H}_{1}\right)$ diterima. Penelitian ini membuktikan sinyal merupakan tindakan yang diambil manajemen perusahaan, yang dapat memberikan petunjuk bagi investor tentang bagaimana manajemen memandang prospek perusahaan. Hasil penelitian ini mendukung temuan Profilet \& Bacon (2013) yang melakukan penelitian di pasar saham US bahwa ukuran perusahaan berhubungan negatif dengan volatilitas harga saham. Demikian juga dalam penelitian Hashemijoo, et al. (2012), Shah \& Noreen (2016) dan Jahfer \& Mulafara (2016) menunjukkan pengaruh negatif ukuran perusahaan terhadap volatilitas harga saham. Dimana saham perusahaan kecil lebih likuid dibanding perusahaan besar, sehingga menyebabkan harga sahamnya lebih volatil. 
Perusahaan besar memiliki diversifikasi aktivitas dan informasi publik yang lebih banyak sehingga mampu menurunkan volatilitas harga saham.

Penelitian ini dapat membuktikan teori sinyal yang diartikan sebagai suatu tindakan yang diambil manajemen perusahaan (yaitu dapat dilihat dari bagaimana perusahaan seharusnya memposisikan laba maupun pembagian dividen), yang dapat memberikan petunjuk bagi investor tentang bagaimana manajemen memandang prospek perusahaan agar investor dapat mengambil keputusan berinvestasi yang selanjutnya berdampak pada volatilitas harga saham. Penelitian ini juga membuktikan tidak semua variabel yang secara teori memengaruhi volatilitas harga saham ketika dilakukan penelitian berpengaruh secara nyata, hal ini dapat terjadi karena adanya perbedaan obyek penelitian, periode penelitian, dan kondisi yang berbeda.

Penelitian memberikan kontribusi positif bagi semua pihak khususnya pihak perusahaan dan investor. Bagi pihak perusahaan selalu perhatikan pencapaian investasi saham yang optimum bagi perusahaan melalui kenaikan laba yang konsisten dan asset perusahaan yang mampu meningkatkan harga saham. Bagi pihak investor dalam berinvestasi di pasar modal tetap memperhatikan tingkat volatilitas laba, dividen yield, dan ukuran perusahaan yang akan diinvestasikan, karena dilihat dari koefisien determinasi sebesar 17,3\% dapat menjelaskan tingkat volatilitas harga saham. Untuk meminimalisir kesalahan dalam berinvestasi di pasar modal. 
Ni Wayan Sekar Andiani dan Gayatri. Pengaruh...

\section{SIMPULAN DAN SARAN}

Dari hasil penelitian, dapat disimpulkan bahwa volume perdagangan saham tidak berpengaruh terhadap volatilitas harga saham. Konsep supply dan demand menunjukkan harga saham akan naik akibat banyaknya investor yang menginginkan saham tersebut. Akan tetapi faktor yang menentukan perubahan harga saham, tidak hanya faktor permintaan dan penawaran saham saja, melainkan tren dan situasi ekonomi makro yang terjadi pada periode tertentu juga mendasari pergerakan harga saham. Selain itu perbedaan komoditi yang diperjual belikan pada setiap sampel perusahaan juga dapat mengakibatkan perbedaan volume perdagangannya. Volatilitas laba berpengaruh negatif pada volatilitas harga saham. Para investor menggunakan ukuran tingkat volatilitas laba untuk memprediksi harga saham di pasar modal. Naik turunnya laba dapat membuat perusahaan sulit mendapatkan dana eksternal, karena perusahaan tidak stabil. Hal ini disebabkan karena faktor risiko yang dihasilkan akibat fluktuasi laba yang tinggi. Yakni semakin tinggi volatilitas laba yang dimiliki perusahaan cenderung mengurangi minat investor untuk menanamkan modalnya di pasar modal atau dapat menurunkan tingkat volatilitas harga saham. Harga saham perusahaan mengalami kenaikan maupun penurunan akibat keputusan investor membeli atau menjual saham. Dividend yield berpengaruh positif pada volatilitas harga saham. Meningkatnya dividend yield dapat berpengaruh pada tinggi rendahnya minat investor untuk menanamkan modalnya di pasar modal dan berdampak bagi para pemegang saham. Peningkatan dividen yang dibayarkan dapat dianggap sebagai sinyal yang menguntungkan bagi investor dan para pemegang saham, sehingga 
menimbulkan reaksi harga saham yang positif. Yaitu meningkatnya harga saham disebabkan oleh kemampuan perusahaan menghasilkan laba yang tinggi, dan juga diiringi tingginya dividen yang dibagikan. Ukuran perusahaan berpengaruh negatif pada volatilitas harga saham. Hal ini disebabkan oleh semakin besarnya ukuran perusahaan maka diversifikasi aktivitas semakin besar. Informasi publik yang dimiliki perusahaan besar lebih banyak sehingga dapat menurunkan tingkat volatilitas harga saham.

Berdasarkan hasil penelitian ini, saran-saran yang dapat diberikan yaitu: penelitian selanjutnya dapat membahkan faktor eksternal sebagai variabel di dalam menentukan volatilitas harga saham seperti tingkat inflasi dan tingkat suku bunga. Selain itu peneliti selanjutkan juga dapat melakukan penelitian yang serupa dengan mengambil sektor perusahaan yang berbeda agar hasil yang diperoleh nantinya memiliki cakupan lebih luas. Bagi perusahaan di Indonesia selalu memerhatikan faktor-faktor yang dapat meningkatkan harga saham dan pencapaian investasi saham yang optimum bagi perusahaannya, khususnya faktor yang berasal dari dalam atau faktor internal seperti volatilitas laba, ukuran perusahaan dan pembagian dividen. Bagi investor dalam berinvestasi di pasar modal tetap memperhatikan return dan resiko yang mencerminkan fluktuasi harga saham dengan melihat tingkat volatilitas laba, dividend yield, dan ukuran perusahaan yang akan diinvestasikan. Untuk meminimalisir kesalahan dalam berinvestasi di pasar modal.

\section{DAFTAR REFERENSI}

Admati, A. R., \& Pfleiderer, P. (1988). A Theory of Intraday Patterns: Volume and Price Variability. The Review of Financial Studies, 1(1), 3-40. 
Agustinus, Gumanti, T. A., Mufidah, A., \& Tulelehu, A. (2013). Volume Perdagangan, Frekuensi Perdagangan, Order Imbalance, dan Volatilitas Harga Saham. Jurnal Universitas Paramadina, 10(2).

Anastassia, \& Firnanti, F. (2014). Faktor-faktor yang Mempengaruhi Volatilitas Harga Saham Pada Perusahaan Publik Non-Keuangan. Jurnal Bisnis Dan Akuntansi, 16(2), 95-102.

Anggana, R. P. (2013). Analisis Pengaruh Rasio Pasar sebagai Tolok Ukur Penembalian Investasi Terhadap Harga Saham Pada Perusahaan LQ 45 dan JII Bursa Efek Indonesia (BEI) Selama Tahun 2008-2011. Universitas Sebelas Maret Surakarta.

Anwar, S., Singh, S., \& Jain, P. K. (2015). Cash Dividend Announcements and Stock Return Volatility: Evidence from India. Journal of Procedia Economics and Finance, 30(15), 38-49.

Aziz, M., Mintarti, S., Nadir, M. (2015). Manajemen Investasi Fundamental, Teknikal, Perilaku Investor dan Return Saham. Yogyakarta: DEEPUBLISH (Grup Penerbitan CV BUDI UTAMA).

Baskin, J. (1989). Dividend Policy and the Volatility of Common Stock. Journal of Portfolio Management, 15(3), 19-25.

Brigham, E., \& Houston, J. F. (2001). Manajemen Keuangan II. Jakarta: Salemba Empat.

Daigler, R. T., \& Wiley, M. K. (1999). The Impact of Trader Type on the Futures Volatility-Volume Relation. The Journal of Finance, 54(6), 2297-2316.

Darmadji, T., \& Fakhruddin. (2012). Pasar Modal di Indonesia (Edisi Keti). Jakarta: Salemba Empat.

Dewi, N. M. A. K., \& Suaryana, I. G. N. A. (2016). Pengaruh Volume Perdagangan Saham, Leverage, dan Tingkat Suku Bunga Terhadap Volatilitas Harga Saham. E-Jurnal Akuntansi Universitas Udayana, 17(2), 1112-1140.

Epps, T. W. (1976). The Stochastic Dependence of Security Price Changes and Transaction Volumes: Implications for the Mixture-of-Distributions Hypothesis. Journal of the Econometric Society, 44(2), 305-321.

Fajrihan, J. (2010). Dampak Kebijakan Dividen Terhadap Volatilitas Harga Saham Perusahaan LQ 45 di BEI. Universitas Islam Negeri Syarif Hidayatullah. 
Fauziah, N. (2013). Analisis Pengaruh Volume Perdagangan, Inflasi, Dividend Yield dan Dividend Payout Ratio Terhadap Volatilitas Harga Saham Perusahaan yang Terdaftar di LQ 45. Universitas Islam Negeri Syarif Hidayatullah.

Fiechter, P. (2011). The Effects of the Fair Value Option under IAS 39 on the Volatility of Bank Earnings. Journal of International Accounting Research, 10(1), 85-108.

Ghozali, I. (2012). Analisis Multivariate Lanjutan dengan Program SPSS. Semarang: Badan Penerbit Universitas Diponegoro.

Ghozali, I. (2013). Aplikasi Analisis Multivariate dengan Program IBM SPSS 21 Up Date PLS Regresi (Edisi ke 7). Semarang: Badan Penerbit Universitas Diponegoro.

Godfrey, J., Hodgson, A., Tarca, A., Hamilton, J., \& Holmes, S. (2010). Accounting Theory (7th ed.). United States of America: John Wiley \& Sons.

Habib, Y., Kiani, Z. I., \& Khan, M. A. (2012). Dividend Policy and Share Price Volatility: Evidence from Pakistan. Global Journal of Management and Business Research, 12(5), 78-84.

Hashemijoo, M., Ardekani, A. M., \& Younesi, N. (2012). The Impact of Dividend Policy on Share Price Volatility in the Malaysian Stock Market. Journal of Business Studies Quarterly, 4(1), 111-129.

Hugida, L. (2011). Analisis Faktor-faktor Yang Mempengaruhi Volatilitas Harga Saham (Studi pada Perusahaan yang Terdaftar dalam Indeks LQ45 Periode 2006-2009). Universitas Diponegoro.

Hussainey, K., Mgbame, C. O., \& Chijoke-Mgbame, A. M. (2011). Dividend Policy and Share Price Volatility: UK Evidence. Journal of Risk Finance, 12(1), 57-68.

Jahfer, A., \& Mulafara, A. H. (2016). Dividend Policy and Share Price Volatility: Evidence from Colombo Stock Market. International Journal of Management and Financial Accounting, 8(2).

Jain, R. K. (2011). Putting Volatility to Work. Retrieved from http://www.activetradermag.com/tradingstrategies.

Jogiyanto, H. (2013). Teori Portofolio dan Analisis Investasi. Yogyakarta: BPFE Yogyakarta. 
Khurniaji, A. W., \& Raharja, S. (2013). Hubungan Kebijakan Dividen ( Dividend Payout Ratio Dan Dividend Yield ) Terhadap Volatilitas Harga Saham Di Perusahaan-Perusahaan Yang Terdaftar Di Bursa Efek Indonesia. Diponegoro Journal of Accounting, 2(3), 1-10.

Misbah, S., Ahmad, S., Muhammad, J. A., Muhammad, S., Sayyad, U.-A., \& Khan, S.-U.-R. (2013). Stock Price Volatility in Relation to Dividend Policy; A Case Study of Karachi Stock Market. Middle-East Journal of Scientific Research, 13(3), 426-431.

Mobarak, R., \& Mahfud, M. K. (2017). Analisis Pengaruh Kebijakan Dividen, BVPS, Earning Volatility, Leverage, PER, dan Volume Perdagangan Terhadap Volatilitas Harga Saham. Diponegoro Journal of Management, 6(2), 1-13.

Nazir, M. S., Abdullah, \& Nawaz, M. M. (2012). How Dividend Policy Affects Volatility of Stock Prices of Financial Sector Firms of Pakistan. American Journal of Scientific Research, (61), 132-139.

Nishat, D. M., \& Irfan, C. M. (2012). Dividend Policy and Stock Price Volatility in Pakistan. The Pakistan Development Review, 4(1), 61-83.

Noviana, S. R., \& Yuyetta, E. N. A. (2011). Analisis Faktor-faktor yang Mempengaruhi Praktik Perataan Laba (Studi Empiris Perusahaan Manufaktur yang Terdaftar di BEI Periode 2006-2010). Jurnal Akuntansi \& Auditing, 8(1), 69-82.

Nuridawati, A. (2015). Kebijakan Dividen Terhadap Volatilitas. Universitas Airlangga.

Parkinson, M. (1980). The Extreme Value Method for Estimating the Variance of the Rate of Return. The Journal of Business, 53(1), 61-65.

Profilet, K. A., \& Bacon, F. W. (2013). Dividend Policy and Stock Price Volatility in the U.S. Equity Capital Market. American Society of Business and Behavioral Sciences, 20(1), 219-231.

Puspitasari, K. D., \& Latrini, M. Y. (2014). Pengaruh Ukuran Perusahaan, Anak Perusahaan, Leverage dan Ukuran KAP Terhadap Audit Delay. E-Jurnal Akuntansi Universitas Udayana, 8(2), 283-299.

Ratnasari, A. (2015). Pengaruh Volume Perdagangan, Tingkat Inflasi, dan Nilai Tukar (RP/USD) Terhadap Volatilitas Harga Saham. Universitas Widyatama. 
Rinaldi, Y. (2014). Pengaruh Dividend Payout Ratio, Dividend Yield, Ukuran Perusahaan dan Earning Volatility Terhadap Volatilitas Harga Saham Pada Perusahaan Manufaktur di Bursa Efek Indonesia. Universitas Syiah Kuala Banda Aceh Darussalam.

Rohmawati, I. (2017). Pengaruh Volume Perdagangan, Dividend Payout Ratio dan Inflasi Terhadap Volatilitas Harga Saham Pada Perusahaan yang Terdaftar dalam Indeks LQ 45 Tahun 2011-2015. Fakultas Ekonomi Universitas Negeri Yogyakarta, 6(1).

Rowena, J., \& Hendra. (2017). Earnings Volatility, Kebijakan Dividen, dan Pertumbuhan Asset Berpengaruh Terhadap Volatilitas Harga Saham Pada Perusahaan Manufaktur Di BEI Periode 2013 - 2015. Jurnal Administrasi Kantor, 5(2), 231-242.

Safitri, L. R. (2013). Pengaruh Variabel-variabel Fundamental dan Teknikal Terhadap Harga Saham Pada Perusahaan Manufaktur yang Terdaftar di Bursa Efek Indonesia. Universitas Muhammadiyah Surakarta.

Sandrasari, W. T. (2010). Analisis Pengaruh Volume Perdagangan, Frekuensi Perdagangan, dan Order Imbalance Terhadap Volatilitas Harga Saham Pada Perusahaan Go Public di Bursa Efek Indonesia. Universitas Sebelas Maret.

Sartono, R. A. (2010). Manajemen Keuangan Teori dan Aplikasi (Edisi Keem). Yogyakarta: BPFE.

Schwert, G. W., \& Smith, J. C. (1992). Empirical Research in Capital Market. USA: McGraw-Hill.

Shah, S. A., \& Noreen, U. (2016). Stock Price Volatility and Role of Dividend Policy: Empirical Evidence from Pakistan. International Journal of Economics and Financial Issues, 6(2), 461-472.

Sova, M. (2013). Pengaruh Ratio Leverage Terhadap Volatilitas Saham Pada Industri Barang Konsumsi Di Bursa Efek Indonesia Tahun 2004-2008, 1(1).

Sudana, I. M. (2011). Manajemen Keuangan Perusahaan Teori dan Praktik. Jakarta: Erlangga.

Sugiono, L. P., \& Christiawan, Y. J. (2013). Analisa Faktor yang Mempengaruhi Likuiditas Pada Industri Ritel yang Terdaftar Pada Bursa Efek Indonesia Tahun 2007-2012. Business Accounting Review, 1(2), 298-305.

Sugiyono. (2014). Metode Penelitian Bisnis (Pendekatan Kuantitatif, Kualitatif dan $R \& D)$. Bandung: Alfabeta. 
Ni Wayan Sekar Andiani dan Gayatri. Pengaruh...

Sutrisno. (2012). Manajemen Keuangan Teori, Konsep dan Aplikasi (8th ed). Yogyakarta: Ekonisia.

Tandelilin, E. (2010). Analisis Investasi dan Manajemen Portofolio (Edisi 7). Yogyakarta: Kanisius.

Tauchen, G., \& Pitts, M. (1983). The Price Variability-Volume Relationship on Spekulative Markets. Econometrica.

Tim Studi Volatilitas Pasar Modal Indonesia dan Perekonomian Dunia. (2011). Volatilitas Pasar Modal Indonesia dan Perekonomian Dunia. BAPEPAM-LK.

Utama, S. (2014). Aplikasi Analisis Kuantitatif (Edisi ke 8). Denpasar: Fakultas Ekonomi Universitas Udayana.

Waluyo, W. (2016). Analisis Determinan Volatilitas Harga Saham. Universitas Negeri Yogyakarta.

Wati, N. K. P. H., \& Ratnasari, M. M. (2015). Rasio Pasar Dan Harga Saham Di Bursa Efek Indonesia Periode 2009-2013. E-Jurnal Akuntansi Universitas Udayana, 10(1), 279-293.

Yesi, Y. A. (2015). Pengaruh Earning Volatility, Dividend Yield, Growth in Asset Dan Size Terhadap Volatilitas Harga Saham Pada Perusahaan Manufaktur Tahun 2011-2013. Universitas Muhammad Surakarta.

Yudiana, I. G. Y., \& Yadnyana, I. K. (2016). Pengaruh Kepemilikian Manajerial, Leverage, Investment Opportunity Set dan Profitabilitas pada Kebijakan Dividen Perusahaan Manufaktur. E-Jurnal Akuntansi Universitas Udayana, 15(1), 112-141.

Zakaria, Z., Muhammad, J., \& Zulfikli, A. H. (2012). The Impact of Dividend Policy on the Share Price Volatility: Malaysian Construction and Material Companies. International Journal of Economics and Management Sciences, $2(5), 1-8$.

Zulfa, N. A. (2015). Analisis Estimasi Volatilitas Indeks Harga Saham Menggunakan Harga Tertinggi, Terendah, Pembukaan, dan Penutupan. Universitas Negeri Semarang. 